\title{
Investigation of Central Anatolian region Nigde-Dikilitas (Turkey) clays by FTIR spectroscopy
}

\author{
BURHAN DAVARCIOGLU - Department of Physics, University of Aksaray, Turkey • \\ burdavog@hotmail.com \\ Received: 17.11.2009. - Érkezett: 2009.11.17. http://dx.doi.org/10.14382/epitoanyag-jsbcm.2010.12
}

The clay samples taken from studied area Nigde-Dikilitas located place in the northeast part of Nigde province in the Central Anatolian region have been investigated by means of FTIR spectroscopy. Firstly, the FTIR spectra of beidellite, illite, illite-smectite mixed layer, kaolinite, chlorite (ripidolite), nontronite, montmorillonite, Ca-montmorillonite, Na-montmorillonite known as standard natural clays and then anhydrite, gypsum, quartz+feldspar, illite+quartz+feldspar clays to be found in clays with the standard clays have been also taken, respectively. The minerals have been determined by comparing the spectrum of every sample with the spectra of the standard clays and combined clays. It has been observed that the existence of the O-H, Al-Al-OH, Al-Mg-OH, and Si-O-Si groups in the FTIR spectrum measurements of the samples belonging to the lower, middle and upper levels of Dikilitas clay profiles (D1), (D2, D3), and (D4), respectively. In addition, it has been found that these samples including quartz, amorphous silica, feldspar, and Na-montmorillonite and these silicate samples have a T-O-T (tetrahedral-octahedral-tetrahedral) smectite structure.

Keywords: Nigde, clay, FTIR, montmorillonite, feldspar, smectite
Dr. Burhan DAVARCIOGLU Hacettepe University, Ankara-Turkey, Faculty of Engineering in 1978, enters as the Engineer graduated from the Physics. Nuclear Medicine Department in the years 1984-1985 at Hacettepe University, Radiation Physics and Radioisotope Laboratories has participated in the creation work. Works as a Research Fellow (1985-1993) in Gazi University, Institute of Science and Technology, Department of Physics, in 1987, "Solid-State Lasers" with his Master's thesis, and in 1992, "Some Complex and Clathrates Infra-red Spectroscopy Investigation" of the named PhD thesis completed. Faculty Member appointed as he took active part in the founding, Nigde University in 1994. Faculty of Arts and Sciences Department of Physics and Institute of Science and Technology the establishment of many administrative tasks found. Turkish National Committee on Clay Science is member and New York Academy of Sciences is an active member. Papers presented at the international level to the majority and the broadcast Dr. Davarcioglu's many references were made to run. Of interest related to the study of various summer schools participated. Since the year 2000 , industrial raw materials quality and quantity of clay, by means of the spectroscopic identification of the work operates. Aksaray University, was appointed in April of 2007 to the relay.

\section{Introduction}

Clay is a general name for an important mineral group which is used for the production of great number products, encompasses every part of daily life, such as from soil to ceramics and from fine arts to advanced technological industry [1]. The past few decades have seen increasing use clays in a wide range of fields such as production from paper industry to ceramics, bleaching of the vegetable oils, beer, wine and fruit juices, cleaning of the radioactive wastes and waste waters, and production of drugs, perfumes, soaps, detergents, rubbers and plastics [1, 2, 3 and 4]. Researchers are interested in studying the physical and chemical properties of the clays to increase their applications in different fields [5].

The structure of the clay organic complexes has been the subject of many researches since 1930 [6]. Some clay minerals having large surface area, high ion exchange capacity and molecular grid properties have been pioneered for the development of many new products [4]. On the other hand, it is very important to know the chemical properties of the clays in applications. One of the methods applied is the FTIR (Fourier Transform Infrared) spectroscopy [7, 8, 9 and 10]. Significant number of studies, generally on the geology of the study area is available in the literature. However, particularly one of them, which are more comprehensive study in terms of geology and mineralogy, deserves to be mentioned here. Therefore, many studies have been carried out to determine the chemical properties of the Anatolian clays [9, 10 and 16]. In this kind of studies, FTIR spectrophotometer is one of the most employed methods.

An earlier attempt to determine the chemical properties of the Anatolian clays using the FTIR spectroscopy was successful to certain extent [11]. In this study, the adsorption of 2 , 2'-biquinoline onto natural and ion-exchanged montmorillonite and saponite from Anatolia (Turkey) have been studied. In a similar study, the adsorption of 3-aminopyridine by natural sepiolite and montmorillonite from Anatolia (Turkey) have been investigated in the temperature range from 20 to $125^{\circ} \mathrm{C}$ using a variable temperature unit [12]. They have also studied the adsorption of pyrimidine on natural montmorillonite and sepiolite from Turkey [13]. In addition to these studies, there are some studies carried out on the clays which take place in the studied area. In one of these studies, Dikilitas clays (Fig. 1.) have been studied and it has been determined that the clays belonging to lower level, middle level, and upper level have been formed with sand and gravel having a color yellow-gray, greenish and red, respectively [14]. In the same region, the other study has been carried out on the geological formation of the clays by a researcher [15]. He has shown that the clays have been deposited terrestrial and lacustrine. But, no study on the quality and the quantity of the region's clays has been document yet.

Along with XRD (X-ray powder diffraction), the FTIR investigation in clay mineral speciation could be regarded as useful and multipurpose application since some physical details of clay lattices and experimental qualitative correlation between the samples were made possible. Besides, for the minerals that were observed with the both techniques, functional groups could only be determined through the FTIR spectra. Therefore, qualitative and quantitative speciation of the minerals by employing the FTIR spectroscopy is very important and promising. In this study, the clay samples taken from Nigde-Dikilitas located in the Central Anatolian (Turkey) have been investigated by using the FTIR spectroscopy.

\section{Materials and methods}

A combined profile representing the constructed profiles chosen for this and nearby area was shown in Fig. 1. 
The clay samples were taken from three different levels shown in the litostratigraphic columnar section of a selected locality in Nigde-Dikilitas region (Fig. 2.). The samples taken from lower level, middle level and upper level labeled as (D1), (D2, D3), and (D4), respectively.

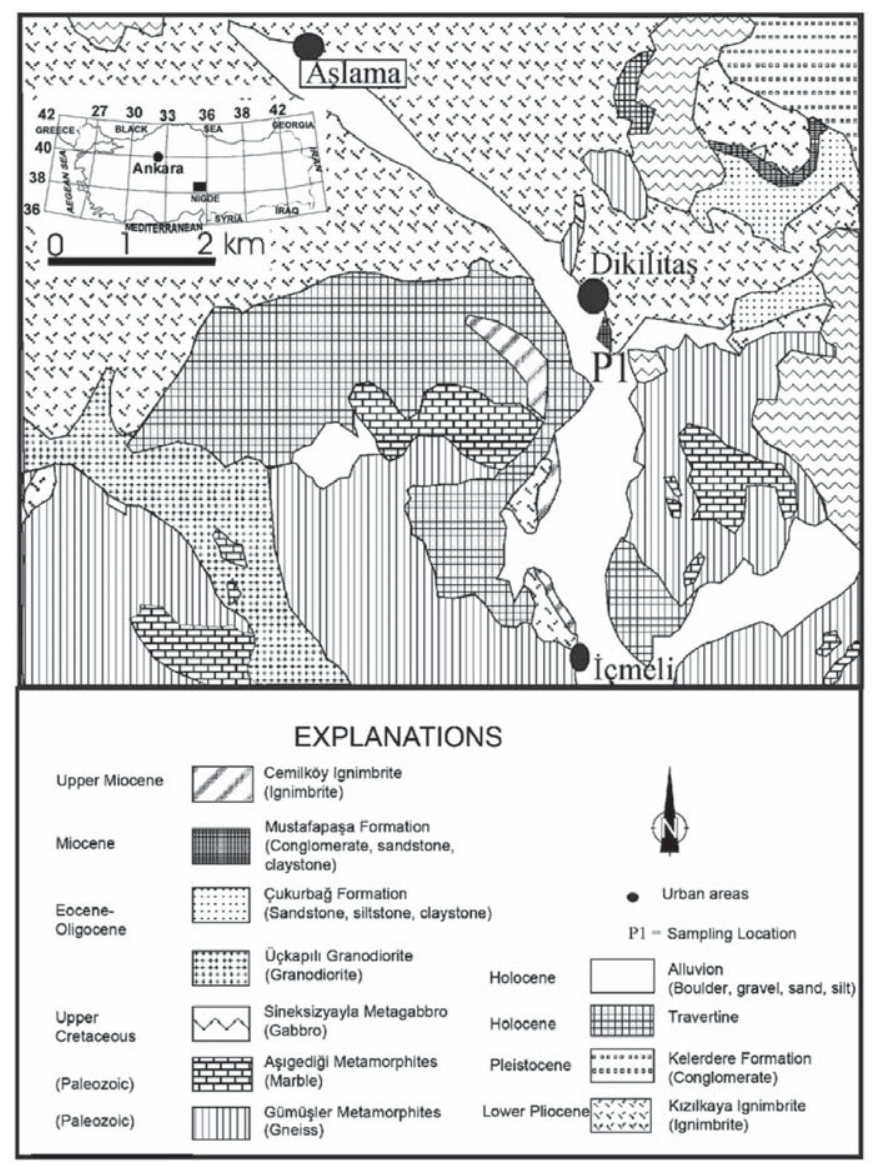

Fig. 1. Generalized geological map of the study area [16]

1. ábra A vizsgált terület általános geológiai térképe [16]

The following processes were applied to prepare the samples for the FTIR measurements. Samples were ground into powder. Powdered samples were alternately washed with pure water, ethyl alcohol, and ether. Then, they were dried in an oven at $110^{\circ} \mathrm{C}$ for 24 hours. These samples were prepared applying the disc technique (mixing $\sim 1 \mathrm{mg}$ clay sample with $\sim 200 \mathrm{mg} \mathrm{KBr}$ ) and put in molds. These intimate mixtures were then pressed at very high pressure (10 tons per $\mathrm{cm}^{2}$ ) to obtain the transparent discs, which were then placed in the sample compartment. Bruken Equinox 55 Fourier transform FTIR spectrophotometer (Department of Physics, Middle East Technical University, Ankara-Turkey) was used for the IR spectral measurements of these samples with standard natural clay and the spectra were recorded over the range of $5000-370 \mathrm{~cm}^{-1}$ (\% transmission versus $\left.\mathrm{cm}^{-1}\right)$. Before taking the spectra measurements of the samples, spectrophotometer was calibrated with polystryrenes and silicate oxide of thickness $0.05 \mathrm{~nm}$.

On the other hand, the infrared spectra of the beidellite (SBId-1; Idoha, USA), illite (IMt-1; Silver Hill, Montana, USA), illite-smectite mixed layer (ISMt-1; Mancos Shale, Ord.), kaolinite (KGa-1; Washington Country, Georgia, USA), chlorite (ripidolite, CCa-1; Flagstaff Hill, El Dorato Country,
California, USA), nontronite (NAu-2; Uleynine, South Australia), montmorillonite (SCa-3; Otay, San Diego Country California, USA), Na-montmorillonite(SWy-1; Crook Country, Wyoming, USA), and Ca-montmorillonite (STx; Gonzales Country, Texas, USA) known as standard natural clays were taken, since those spectra were necessary for the analyses of subject samples.

A second treatment was employed only to the clay sample taken from the lover level (D1) to see whether there is a change in the structure of the samples or not due to FTIR spectrum measurements. For this procedure, $\mathrm{HCl}$, bicarbonate $\left(\mathrm{Na}_{2} \mathrm{CO}_{3}\right)$, and sodiumdithonit $\left(\mathrm{Na}_{2} \mathrm{~S}_{2} \mathrm{O}_{4}\right)$, and sodiumstrate $\left(\mathrm{Na}_{3} \mathrm{C}_{6} \mathrm{H}_{5} \mathrm{O}_{7}\right)$ liquids were added to the sample to remove carbonates (mainly calcite and dolomite), amorphous materials and manganese oxides, which were expected to be present. This mixture was treated in an oven at $120{ }^{\circ} \mathrm{C}$ for 24 hours and washed using ethyl alcohol and ether until complete removal of those unwanted components was achieved. The FTIR spectrum of the precipitate was then taken.

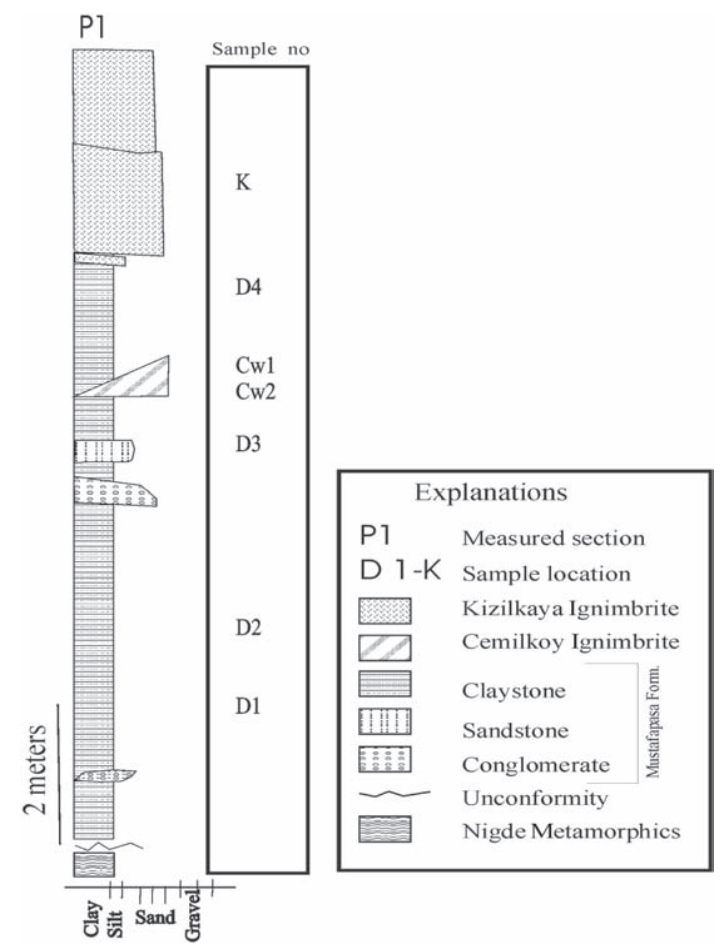

Fig. 2. Generalized litostratigraphic columnar section of Nigde-Dikilitas [16] 2. ábra A Nigde-Dikitas elöfordulás általános litostratigráfiai keresztmetszete[16]

The chemical analyses of the clay samples were carried out at the General Directorate of Mineral Research and Exploration (MTA, Ankara-Turkey) laboratories. Major oxide composition of the samples representing the lower, middle and upper parts of the profile was as follows;

- for the lower part (D1): $64.06 \% \mathrm{SiO}_{2}, 0.58 \% \mathrm{TiO}_{2}$ $12.18 \% \mathrm{Al}_{2} \mathrm{O}_{3}, 5.97 \% \mathrm{Fe}_{2} \mathrm{O}_{3}, 0.03 \% \mathrm{MnO}, 1.89 \% \mathrm{MgO}$ $0.96 \% \mathrm{CaO}, 1.63 \% \mathrm{Na}_{2} \mathrm{O}, 1.44 \% \mathrm{~K}_{2} \mathrm{O}, 0.132 \% \mathrm{Cr}_{2} \mathrm{O}_{3}$, $0.03 \% \mathrm{P}_{2} \mathrm{O}_{5}$;

- for the middle part (D2): $65.45 \% \mathrm{SiO}_{2}, 0.59 \% \mathrm{TiO}_{2}$, $11.80 \% \mathrm{Al}_{2} \mathrm{O}_{3}, 5.83 \% \mathrm{Fe}_{2} \mathrm{O}_{3}, 0.16 \% \mathrm{MnO}, 2.22 \% \mathrm{MgO}$, $1.22 \% \mathrm{CaO}, 1.63 \% \mathrm{Na}_{2} \mathrm{O}, 1.45 \% \mathrm{~K}_{2} \mathrm{O}, 0.102 \% \mathrm{Cr}_{2} \mathrm{O}_{3}$, $0.04 \% \mathrm{P}_{2} \mathrm{O}_{5}$; 
- $\quad$ for the middle part (D3): $68.83 \% \mathrm{SiO}_{2}, 0.56 \% \mathrm{TiO}_{2}$, $11.26 \% \mathrm{Al}_{2} \mathrm{O}_{3}, 4.96 \% \mathrm{Fe}_{2} \mathrm{O}_{3}, 0.10 \% \mathrm{MnO}, 1.90 \% \mathrm{MgO}$, $1.07 \% \mathrm{CaO}, 1.78 \% \mathrm{Na}_{2} \mathrm{O}, 1.60 \% \mathrm{~K}_{2} \mathrm{O}, 0.114 \% \mathrm{Cr}_{2} \mathrm{O}_{3}$, $0.06 \% \mathrm{P}_{2} \mathrm{O}_{5}$;

- $\quad$ and for the upper part (D4): $59.53 \% \mathrm{SiO}_{2}, 0.63 \% \mathrm{TiO}_{2}$, $13.56 \% \mathrm{Al}_{2} \mathrm{O}_{3}, 7.05 \% \mathrm{Fe}_{2} \mathrm{O}_{3}, 0.15 \% \mathrm{MnO}, 2.64 \% \mathrm{MgO}$, $1.28 \% \mathrm{CaO}, 1.03 \% \mathrm{Na}_{2} \mathrm{O}, 1.49 \% \mathrm{~K}_{2} \mathrm{O}, 0.057 \% \mathrm{Cr}_{2} \mathrm{O}_{3}$, $0.01 \% \mathrm{P}_{2} \mathrm{O}_{5}$. These data suggest that the clays of the region are essentially rich in $\mathrm{SiO}_{2}$ and $\mathrm{Al}_{2} \mathrm{O}_{3}$.

\section{Results and discussion}

FTIR spectra of the samples taken from lower level (D1), middle level (D2), and upper level (D4) of Nigde-Dikilitas (Turkey) clay profile are given in Figs. 3-5., respectively.

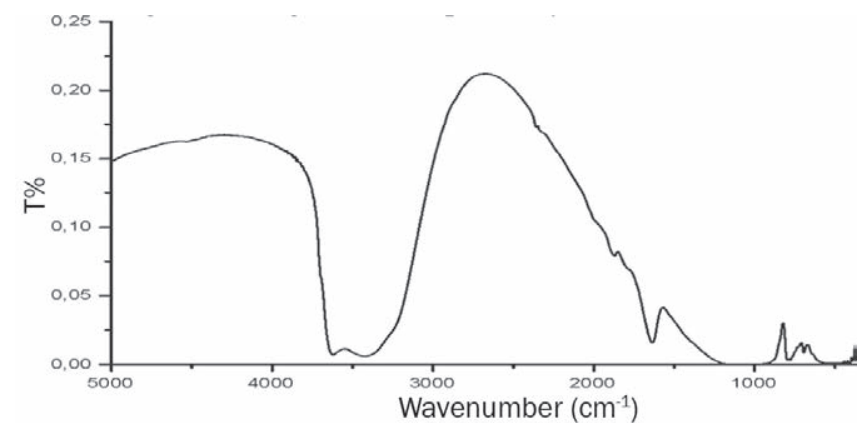

Fig. 3. FTIR spectrum of the clay sample taken from the lower level (D1) of NigdeDikilitas profile

3. ábra A Nigde-Dikitas előfordulás alsó szintjéröl vett (D1) agyagminta FTIR spektruma

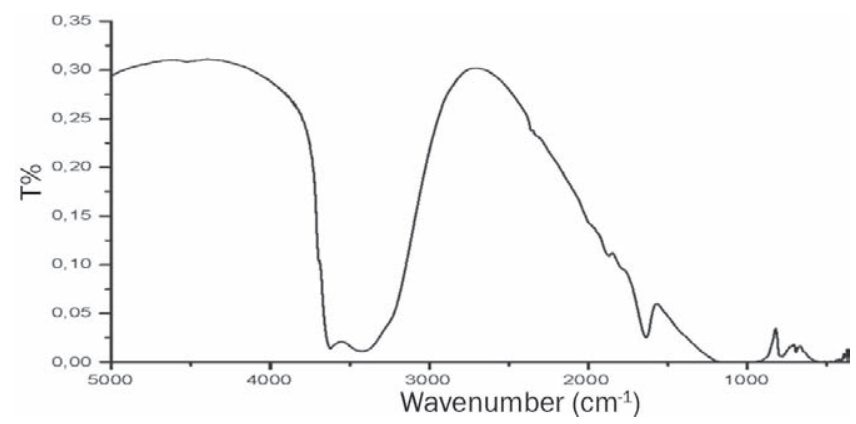

Fig. 4. FTIR spectrum of the clay sample taken from the middle level (D2) of NigdeDikilitas profile

4. ábra A Nigde-Dikitas elöfordulás középsö szintjéröl vett (D2) agyagminta FTIR spektruma

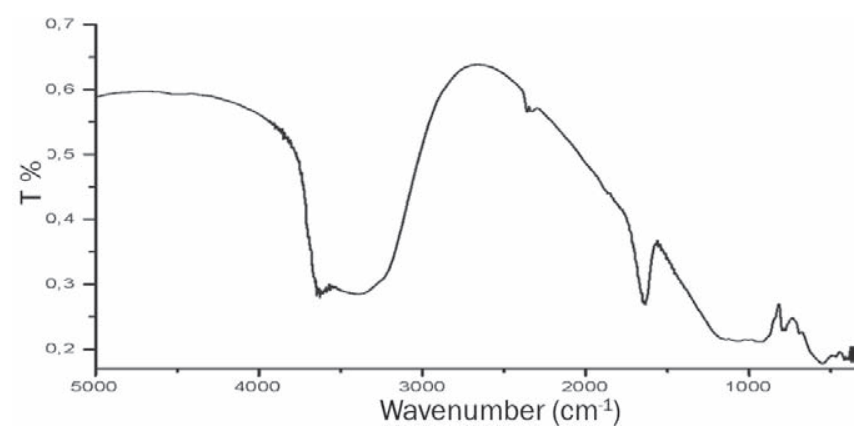

Fig. 5. FTIR spectrum of the clay sample taken from the upper level (D4) of NigdeDikilitas profile

5. ábra A Nigde-Dikitas elöfordulás felső szintjéröl vett (D4) agyagminta FTIR spektruma
The assignments of the vibration bands of the samples were carried out as stated in the materials and methods: using the fundamental vibration frequencies of the clays known as the World Source Clay Minerals (standard natural clay), each of the vibration bands corresponding to which clay species in the spectra of the samples were determined and results for the clay samples given below and the results obtained for each clay sample representing certain levels within the profiles were given in Table 1.

\begin{tabular}{|c|c|}
\hline \multicolumn{2}{|c|}{$\begin{array}{l}\text { Fundamental vibrational frequencies of } \\
\text { illite standard natural clay }\left(\mathrm{cm}^{-1}\right)\end{array}$} \\
\hline$v(\mathrm{OH})$ stretching & 3622 \\
\hline$v(\mathrm{Si}-\mathrm{O})$ normal to the plane stretching & 1090 \\
\hline$v($ Si-O) planar stretching & 1031 \\
\hline (Al-Al-OH) deformation & 916 \\
\hline (Al-Mg-OH) deformation & 832 \\
\hline (Al-O-Si) inner surface vibration & 756 \\
\hline OH deformation & 688 \\
\hline OH deformation & 622 \\
\hline (O-Si-O) bending & 525 \\
\hline (O-Si-O) bending & $468[17]$ \\
\hline
\end{tabular}

\begin{tabular}{|c|c|}
\hline \multicolumn{2}{|c|}{$\begin{array}{l}\text { Fundamental vibrational frequencies of } \\
\text { chlorite (ripidolite) standard natural clay }\left(\mathrm{cm}^{-1}\right)\end{array}$} \\
\hline$v(\mathrm{OH})$ stretching & 3662 \\
\hline$v(\mathrm{OH})$ stretching & 3565 \\
\hline$v(\mathrm{OH})$ stretching & 3434 \\
\hline$v(\mathrm{SiO})$ stretching & 988 \\
\hline $\mathrm{M}-\mathrm{OH}$ stretching & 819 \\
\hline Si-O deformation & 766 \\
\hline $\mathrm{OH}$ deformation & 667 \\
\hline (Si-O-Al) deformation & 543 \\
\hline (Si-O-Mg) deformation & 441 [17] \\
\hline
\end{tabular}

\begin{tabular}{|c|c|}
\hline \multicolumn{2}{|c|}{$\begin{array}{l}\text { Fundamental vibrational frequencies of } \\
\text { Na-montmorillonite standard natural clay }\left(\mathrm{cm}^{-1}\right)\end{array}$} \\
\hline Inner-layer $\mathrm{OH},(\mathrm{Al}-\mathrm{O} . . . \mathrm{H})$ stretching & 3680 \\
\hline$v(\mathrm{OH})$ stretching "shoulder" & 3627 \\
\hline$v(\mathrm{OH})$ stretching & 3622 \\
\hline (Al-Al-OH) deformation & 920 \\
\hline (Al-Fe-OH) deformation & 890 \\
\hline (Al-Mg-OH) deformation & 875 \\
\hline M-OH stretching & 805 \\
\hline $\mathrm{OH}$ deformation & 620 \\
\hline (O-Si-O) bending & 520 \\
\hline (O-Si-O) bending & $468[18]$ \\
\hline
\end{tabular}

$\begin{aligned} & \text { Fundamental vibrational frequencies of } \\
& \left.\text { Ca-montmorillonite standard natural clay } \mathbf{( c m}^{-1}\right)\end{aligned}$
\begin{tabular}{lc} 
Inner-layer $\mathrm{OH},(\mathrm{Al}-\mathrm{O} . . . \mathrm{H})$ stretching & 3670 \\
\hline $\mathrm{v}(\mathrm{OH})$ stretching “shoulder" & 3627 \\
\hline $\mathrm{v}(\mathrm{OH})$ stretching & 3622 \\
\hline (Al-Al-OH) deformation & 905 \\
\hline (Al-Mg-OH) deformation & 840 \\
\hline $\mathrm{M}-\mathrm{OH}$ stretching & 795 \\
\hline $\mathrm{OH}$ deformation & 625 \\
\hline (O-Si-O) bending & 520 \\
\hline (O-Si-O) bending & $468[18]$
\end{tabular}




\begin{tabular}{|c|c|c|c|c|}
\hline & D1 & D2 & D4 & \\
\hline Assignment & & Wavenumber $\left(\mathrm{cm}^{-1}\right)$ & & Clay mineral type \\
\hline \multicolumn{5}{|l|}{ Inner-layer $\mathrm{OH}$, } \\
\hline$(\mathrm{Al}-\mathrm{O} \ldots \mathrm{H})$ stretching & 3680 & 3680 & 3680 & Na-Montmorillonite \\
\hline$v(\mathrm{OH})$ stretching "shoulder" & - & 3627 & 3627 & Na-Montmorillonite \\
\hline$v(\mathrm{OH})$ stretching & 3622 & 3622 & 3622 (broadening) & Na-Montmorillonite \\
\hline (Al-Al-OH) deformation & 920 & 920 & 920 & Na-Montmorillonite \\
\hline (Al-Mg-OH) deformation & 875 & 875 & 875 & Na-Montmorillonite \\
\hline $\mathrm{M}-\mathrm{OH}$ stretching & 804 & 804 & 804 & Na-Montmorillonite \\
\hline$v(\mathrm{OH})$ stretching & 800 & 800 & 800 & Feldspar \\
\hline$v(\mathrm{OH})$ stretching & 797 & 797 & 797 & Amorphous Silica/Quartz \\
\hline$v(\mathrm{OH})$ stretching & 788 & 788 & 788 & Quartz \\
\hline$v(\mathrm{OH})$ stretching & 697 & 697 & 697 & Quartz \\
\hline $\mathrm{OH}$ deformation & 625 & 625 & 623 & Ca-Montmorillonite \\
\hline (O-Si-O) bending & 523,468 & 523,468 & 520,468 & Na-Montmorillonite \\
\hline
\end{tabular}

Table 1. FTIR spectrum analysis results of Nigde-Dikilitas clay samples D1, D2, and D4 belonging to lower, middle, and upper levels, respectively 1. táblázat A Nigde-Dikitas előfordulás alsó (D1), középső (D2) és felső (D4) szintjéröl vett agyagminták FTIR spektrumainak elemzési adatai

As mentioned above, the assignments of vibration band components of the clay samples seen in FTIR spectra were performed using the vibration band components of the natural clays. After these assignments, it was determined which type of clay minerals each vibration band of clay sample belongs to. The results are given Table 1. As seen from this table, all of the samples belonging to the lower, middle and upper levels of Nigde-Dikilitas (Turkey) clay profiles D1, D2, and D4 respectively, include quartz, amorphous silica, feldspar, and $\mathrm{Na}$-montmorillonite minerals. It means that these clays have the framework of silicate structure, such as T-O-T (tetrahedral-octahedral-tetrahedral). The main clay mineral in the clay samples is Na-montmorillonite. On the other hand, it has been observed $\mathrm{O}-\mathrm{H}, \mathrm{Al}-\mathrm{Al}-\mathrm{OH}, \mathrm{Al}-\mathrm{Mg}-\mathrm{OH}$, and $\mathrm{Si}-\mathrm{O}-\mathrm{Si}$ groups in their FTIR spectra. This situation is attributed to the substitutions of different atoms in montmorillonite having different valance values displaying in clay samples. It means that silicon and aluminum in the tetrahedral layer can exchange. Since this site exchange will cause an excess of cation and this cation deficiency in the other side is completed with $\mathrm{Na}^{+}$ cations entering these left sites. Hence, Na-montmorillonite octahedral layer taking place between two tetrahedral layers is formed. Because of the weakness of the bonds between them, various ions, organic molecules, and waters enter between these layers. Smectite minerals are formed of one octahedral and two tetrahedral layers overlying on each other. In this case, unit layer 2:1 and this structure are named as T-O-T.

Octahedral layer forms gypsum like structure layer (hydroxyl planar) and tetrahedral layer forms silicate like structure (oxygen planar) in montmorillonite mineral. Organic molecules enforce the silicate layers and may be penetrated into the vacancies among them. They form $\mathrm{H}$-bonding with the surface hydroxyls breaking the strong electrostatic and van der Waals forces between the layers. This hydroxyles planes are weak proton donors, so they can form hydrogen bonds with the strong bases $[19,20]$. Bipolar molecules which behave as both powerly proton donor and acceptor place on the tetrahedral surface giving protons to the oxygens while placing on the octahedral surface taking protons from hydroxyles [21]. Formed hydrogen bonds are very weak since oxygen plane is very weak electron donor. Therefore, the atoms having different valances and substituting on the octahedral layer form $\mathrm{H}$-bonding with inner-surface hydroxyles. On the other hand, different ions and water molecules also go into among the layers since bonding forces between them are very weak. Some small organic molecules and ions take place straight forward among the layers forming $\mathrm{H}$-bonding with the inner surface hydroxyles or oxygen plane of Na-montmorillonite mineral. In this case, this causes frequency shifts as mentioned above.

FTIR spectrum analysis results of the clay sample: there are 10 fundamental vibration frequencies of Na-montmorillonite mineral in the spectrum of standard natural clay. Although, there are little shifts from the fundamental vibration frequencies, all the fundamental frequencies of the $\mathrm{Na}$ montmorillonite mineral were observed. These very small frequency shifts are caused by the water going into among the layers of Na-montmorillonite mineral. $v(\mathrm{OH})$ stretching vibration frequency of $\mathrm{Na}$-montmorillonite mineral of all levels clay at $3680 \mathrm{~cm}^{-1}$. This is inner-layer $\mathrm{OH},(\mathrm{Al}-\mathrm{O} . . . \mathrm{H})$ stretching band of Na-montmorillonite [18]. Na-montmorillonite in standard natural clay is seen at $620 \mathrm{~cm}^{-1}$ (OH deformation) and Ca-montmorillonite in standard natural clay is seen at 625 $\mathrm{cm}^{-1}$ (OH deformation), it was observed at $625 \mathrm{~cm}^{-1}$ for lower level (D1) and middle level (D2), $623 \mathrm{~cm}^{-1}$ for upper level (D4) sample. There is a little shifts.

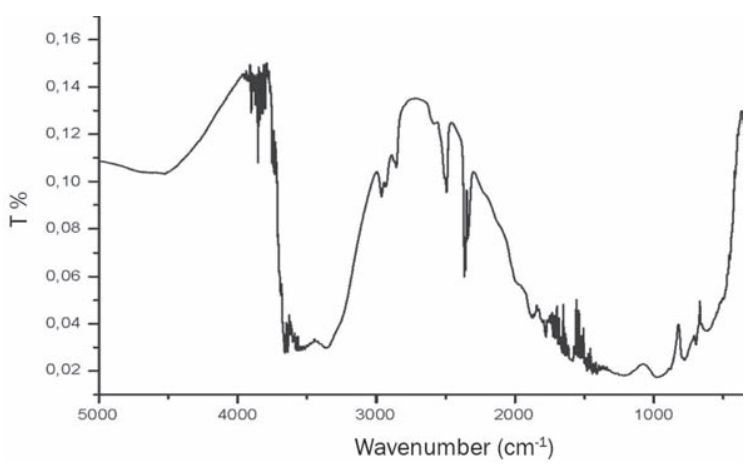

Fig. 6. FTIR spectrum of the clay sample (D1) of Nigde-Dikilitas (Turkey) after thermal treatment

6. ábra A Nigde-Dikitas előfordulás alsó szintjéröl vett (D1) agyagminta hökezelés után felvett FTIR spektruma 


\begin{tabular}{|c|c|c|}
\hline & D1 & O10 \\
\hline Inner-surface $\mathrm{OH},(\mathrm{Al}-\mathrm{O} . . . \mathrm{H})$ stretching & 3680 & Na-Montmorillonite \\
\hline$v(\mathrm{OH})$ stretching & 3662 & Chlorite \\
\hline$v(\mathrm{OH})$ stretching "shoulder" & 3627 & Na-Montmorillonite \\
\hline$v(\mathrm{OH})$ stretching & 3622 & Na-Montmorillonite \\
\hline$v(\mathrm{OH})$ stretching & 3564 & Chlorite \\
\hline$v(\mathrm{OH})$ stretching & 3434 & Chlorite \\
\hline$v(\mathrm{OH})$ stretching & 800 & Feldspar \\
\hline$v(\mathrm{OH})$ stretching & 797 & Amorphous Silica/Quartz \\
\hline$v(\mathrm{OH})$ stretching & 788 & Quartz \\
\hline$v(\mathrm{OH})$ stretching & 697 & Quartz \\
\hline O-Si-O bending & 523 & Na-Montmorillonite \\
\hline O-Si-O bending & 468 & Na-Montmorillonite \\
\hline
\end{tabular}

Table 2. Results of the FTIR spectrum analyses of the clay sample (D1) from Nigde-Dikilitas (Turkey) after thermal treatment

2. táblázat A Nigde-Dikitas elófordulás alsó szintjéröl vett (D1) agyagminta hökezelés utáni felvett FTIR spektrumának elemzési adatai

FTIR spectrum of sample (D1) being applied thermal treatment is seen in Fig. 6. Assignment of the component bands of this sample has been carried out following the same way to assign the other samples and the results are given in Table 2. According to these results, this clay sample includes Na-montmorillonite, chlorite, feldspar, amorphous silica and quartz. When the FTIR spectra of the other samples not being treated with thermal and this sample are compared, although the montmorillonite in the untreated samples have $\mathrm{OH}$ deformation vibration bands at $625 \mathrm{~cm}^{-1}$ it is seen that the same bands of the Ca-montmorillonite in the thermal treated sample disappeared [22]. On the other hand, while deformations (Al-Al-OH) and (Al-Mg-OH) and bending $\mathrm{M}-\mathrm{OH}$ seen in the Na-montmorillonite at 920,875 , and $804 \mathrm{~cm}^{-1}$, respectively; that bands are disappearing after the thermal treatment. However that the new band components such as $v(\mathrm{OH})$ stretching of chlorite at 3662,3564 and $3434 \mathrm{~cm}^{-1}$ were appeared after the thermal treatment. Although $\mathrm{OH}$ deformation vibration bands of montmorillonite at 625 and $623 \mathrm{~cm}^{-1}$ before the thermal treatment of the samples were observed, the vibration bands of Ca-montmorillonite completely disappeared, vibration bands assigned as (Al-Al-OH) deformation at $920 \mathrm{~cm}^{-1}$ and (Al-Mg-OH) deformation $875 \mathrm{~cm}^{-1}$, and $\mathrm{M}-\mathrm{OH}$ stretching at $804 \mathrm{~cm}^{-1}$ of Na-montmorillonite were also disappeared, in addition within lattice $v(\mathrm{OH})$ stretching at $3662 \mathrm{~cm}^{-1}, v(\mathrm{OH})$ stretching at $3564 \mathrm{~cm}^{-1}$ and $\mathrm{v}(\mathrm{OH})$ stretching at $3434 \mathrm{~cm}^{-1}$ of chlorite indicate formation of vibration bands. Formation of these bands during thermal treatment are due to organic molecules intruding into the silicate layers and $\mathrm{Al}$ and $\mathrm{Mg}$ atoms exchanging sites within the clay structures [23].

$v(\mathrm{OH})$ stretching vibrations of quartz at 797, 788 and 697 $\mathrm{cm}^{-1}$ and $v(\mathrm{OH})$ stretching vibrations of feldspar at $800 \mathrm{~cm}^{-1}$ remain the same after the thermal treatment (Fig. 6.). As a result, it can be said that the framework of silicate (T-O-T) structures of Nigde-Dikilitas (Turkey) clay samples has not been destroyed. Since smectite-rich horizons were determined with lower and upper parts of the Mustafapasa Formation, it is suggested here that the area can be a potential prospect for the cement industry.

\section{Acknowledgements}

We would like to thank Turkish Scientific and Technological Research Council (TUBITAK, Turkey) for the financial support (project code: YDABCAG-2005-101Y067). Professor Dr. Cigdem Ercelebi (Physics Department, METU, Turkey) is also gratefully appreciated for the FTIR.

\section{References}

[1] Adams, J. M.: Synthetic organic chemistry using pillared, cation-exchanged and acid-treated montmorillonite catalysts-A review, Applied Clay Science, Vol. 2, No. 4, pp. 309-342. (1987)

[2] Murray, H. H.: Applied clay mineralogy today and tomorrow, Clay Minerals, Vol. 34, No. 1, pp. 39-49. (1999)

[3] Breen, C. - Watson, R. - Madejova, J. - Komadel, P. - Klapyta, Z.: Acid activated organoclays: Preparation, characterization and catalytic activity of acid-treated tetraalkylammonnium exchanged smectites, Langmuir, Vol. 13, No. 24, pp. 6473-6479. (1997)

[4] Falaras, P. - Lezou, F. - Seiragakis, G. - Petrakis, D.: Bleaching properties of alumina-pillared acid-activated montmorillonite, Clays and Clay Minerals, Vol. 48, No. 5, pp. 549-556. (2000)

[5] Murray, H. H.: Overview-clay mineral applications, Applied Clay Science, Vol. 5, No. 5-6, pp. 379-395. (1991)

[6] Smith, C. R.: Base exchange reactions of bentonite and salts of organic bases, Journal of the American Chemical Society, Vol. 56, pp. 1561-1563. (1934)

[7] Madejova, J.: FTIR techniques in clay mineral studies, Vibrational Spectroscopy, Vol. 31, No. 1, pp. 1-10. (2003)

[8] Post, J. L. - Borer, L.: Physical properties of selected illites, beidellites and mixed-layer illite-beidellites from southwestern Idaho, and their infrared spectra, Applied Clay Science, Vol. 22, No. 3, pp. 77-91. (2002)

[9] Davarcioglu, B. - Ciftci, E.: Investigation of Central Anatolian clays by FTIR spectroscopy (Arapli-Yesilhisar-Kayseri, Turkey), International Journal of Natural and Engineering Sciences, Vol. 3, No. 3, pp. 154-161. (2009)

[10] Davarcioglu, B.: Investigation of Eastern Black Sea Region Clays by FTIR Spectroscopy (Rize-Findikli-Camlihemsin, Turkey), Colloquium Spectroscopium Internationale XXXVI, Budapest - Hungary, August 30 - September 3, Book of Abstract, pp. 74. (2009)

[11] Akyüz, S. - Akyüz, T. -Davies, J. E. D.: FT-IR and FT-Raman spectroscopic investigations of adsorption of 2,2'-biquinoline by smectite group clay minerals from Anatolia, Vibrational Spectroscopy, Vol. 22, No. 1-2, pp. 11-17. (2000)

[12] Akyüz, S. - Akyüz, T. - Yakar, A. E.: FT-IR spectroscopic investigation of adsorption of 3-aminopyridine on sepiolite and montmorillonite from Anatolia, Journal of Molecular Structure, Vol. 565-566, pp. 487-491. (2001)

[13] S. Akyüz - T. Akyüz: FT-IR spectroscopic investigation of adsorption of pyrimidine on sepiolite and montmorillonite from Anatolia, Journal of Inclusion Phenomena and Macrocylic Chemistry, Vol. 46, No. 1, pp. 51-55. (2003) 
[14] Pasquare, G.: Geology of the Cenozoic volcanic area of Central Anatolia (Provinces of Kayseri and Nevsehir, Turkey), Atti Accademia Nazionale dei Lincei, Vol. 9, No. 1, pp. 53-204. (1968)

[15] Toprak, V.: Origin of the Quaternary basins developed within the Cappadocian volcanic depression, Central Anatolia, Department of Geological Engineering, Black Sea Technical University, Trabzon - Turkey. Proceedings of 30th Anniversary Symposium, Vol. 1, pp. 327-339. (1996) (in Turkish with English abstract)

[16] Kayali, R. - Gurel, A. - Davarcioglu, B. - Ciftci, E.: Determination of qualitative and quantitative properties of industrial raw materials clays and diatomites in Central Anatolia by spectroscopic methods, TUBITAK-Turkey (project number: YDABCAG-2005-101Y067), pp. 36-115. (2005)

[17] Wilson, M. J.: A handbook of determinative methods in clay mineralogy, Blackie-Son Ltd., London, pp. 308-320. (1987)

[18] Farmer, V. C. -Russell, J. D.: The infrared spectra of layer silicates, Spectrochimica Acta, Vol. 20, pp. 1149-1173. (1964)

[19] Olejnik, S. - Aylmore, L. A. G. - Posner, A. M. -Quirk, J. P.: Infrared spectra of kaolin mineral-dimethyl sulfoxide complexes, Journal of Physical Chemistry, Vol. 72, No. 1, pp. 241-249. (1968)

[20] Thompson, J. G. -Cuff, C.: Crystal structure of kaolinite-dimethylsulfoxide intercalate, Clays and Clay Minerals, Vol.33, No. 5, pp. 490-500. (1985)

[21] Ledoux, R. L. - White, J. L.: Infrared studies of hydrogen bonding interaction between kaolinite surfaces and intercalated potassium acetate, hydrazine, formamide and urea, Journal of Colloid and Interface Science, Vol. 21, No. 2, pp. 127-152. (1966)

[22] Velde, B.: Introduction to clay minerals. Chemistry, Origins, Uses and Environmental Significance, 1st ed. Chapman-Hall, UK. London, pp. 20-23. (1992)

[23] Bishop, J. - Madejova, P. - Komadel, P. - Fröschl, H.: The influence of structural $\mathrm{Fe}, \mathrm{Al}$ and $\mathrm{Mg}$ on the infrared $\mathrm{OH}$ bands in spectra of dioctahedral smectites, Clay Minerals, Vol. 37, No. 4, pp.607-616. (2002)

\section{A Közép-Anatóliában található Nigde-Dikilitas régióból származó agyagok vizsgálata FTIR spektroszkópiával}

FTIR spektroszkópiával vizsgáltunk olyan agyagmintákat, amelyek Közép-Anatóliából, a Nigde tartomány északkeleti részén található Nigde-Dikitas területrôl származtak. A kérdéses agyagminták FTIR spektrumait standard agyagminták spektrumaival együtt vettük fel, és mindkét mintasorozatban a következố természetes agyagásványokat azonosítottuk: beidellit, illit, illit-szmektit vegyes réteg, kaolinit, klorit (ripidolit), nontronit, montmorillonit, Ca-montmorillonit és Na-montmorillonit. Ezek mellett még anhidritet, gipszet, kvarcot+földpátot, illitet+kvarcot+földpátot is kimutattunk a mintákban. Az ásványokat minden esetben úgy azonosítottuk, hogy a spektrumokat a standard minták és a vegyes agyagok spektrumaival hasonlítottuk össze. Azt találtuk, hogy az O-H, Al-Al-OH, Al-Mg-OH és az Si-O-Si csoportok a Dikilitas előfordulás alsó (D1), középsô (D2, D3) és felsô (D4) szintjeibôl származó minták spektrumaiban egyaránt megjelennek. A mintákban kvarc, amorf $\mathrm{SiO}_{2}$, földpát és Na-montmorillonit is található, és ezek tetraéderes-oktaéderes-tetraéderes (T-O-T) szmektit szerkezetūek.

Kulcsszavak: Nigde, agyagok, FTIR, montmorillonit, földpát, szmektit

Ref.: http://dx.doi.org//10.14382/epitoanyag-jsbcm.2010.12

Davarcioglu, B.: Investigation of Central Anatolian region NigdeDikilitas (Turkey) clays by FTIR spectroscopy. Építőanyag, 62. évf. 2. szám (2010), 55-60. p. 